\title{
Cell line-specific oxidative stress in cellular toxicity: A toxicogenomics-based comparison between liver and colon cell models
}

Citation for published version (APA):

Deferme, L., Briede, J. J., Claessen, S. M. H., Cavill, R., \& Kleinjans, J. C. S. (2015). Cell line-specific oxidative stress in cellular toxicity: A toxicogenomics-based comparison between liver and colon cell models. Toxicology in Vitro, 29(5), 845-855. https://doi.org/10.1016/j.tiv.2015.03.007

Document status and date:

Published: 01/08/2015

DOI:

10.1016/j.tiv.2015.03.007

Document Version:

Publisher's PDF, also known as Version of record

Document license:

Taverne

Please check the document version of this publication:

- A submitted manuscript is the version of the article upon submission and before peer-review. There can be important differences between the submitted version and the official published version of record.

People interested in the research are advised to contact the author for the final version of the publication, or visit the DOI to the publisher's website.

- The final author version and the galley proof are versions of the publication after peer review.

- The final published version features the final layout of the paper including the volume, issue and page numbers.

Link to publication

\footnotetext{
General rights rights.

- You may freely distribute the URL identifying the publication in the public portal. please follow below link for the End User Agreement:

www.umlib.nl/taverne-license

Take down policy

If you believe that this document breaches copyright please contact us at:

repository@maastrichtuniversity.nl

providing details and we will investigate your claim.
}

Copyright and moral rights for the publications made accessible in the public portal are retained by the authors and/or other copyright owners and it is a condition of accessing publications that users recognise and abide by the legal requirements associated with these

- Users may download and print one copy of any publication from the public portal for the purpose of private study or research.

- You may not further distribute the material or use it for any profit-making activity or commercial gain

If the publication is distributed under the terms of Article $25 \mathrm{fa}$ of the Dutch Copyright Act, indicated by the "Taverne" license above, 


\title{
Cell line-specific oxidative stress in cellular toxicity: A toxicogenomics-based comparison between liver and colon cell models
}

\author{
L. Deferme*, J.J. Briedé, S.M.H. Claessen, R. Cavill, J.C.S. Kleinjans \\ Department of Toxicogenomics, School of Oncology and Developmental Biology (GROW), Maastricht University, 6200 MD Maastricht, The Netherlands
}

\section{A R T I C L E I N F O}

\section{Article history:}

Received 22 August 2014

Accepted 3 March 2015

Available online 21 March 2015

\section{Keywords:}

Liver

Colon

Oxidative stress

Pathway analysis

Transcriptomics

Toxicity

\begin{abstract}
A B S T R A C T
Imbalance between high reactive oxygen species formation and antioxidant capacity in the colon and liver has been linked to increased cancer risk. However, knowledge about possible cell line-specific oxidative stress-mechanisms is limited. To explore this further, gene expression data from a human liver and colon cell line (HepG2/Caco-2), both exposed to menadione and $\mathrm{H}_{2} \mathrm{O}_{2}$ at six time points $(0.5-1-2-4-8$ and $24 \mathrm{~h}$ ) were compared in association with cell cycle distribution. In total, 3164 unique- and $1827 \mathrm{com}$ mon genes were identified between HepG2 and Caco-2 cells. Despite the higher number of unique genes, most oxidative stress-related genes such as CAT, OGG1, NRF2, NF- $\kappa B$, GCLC, HMOX1 and GSR were differentially expressed in both cell lines. However, cell-specific regulation of genes such as KEAP1 and GCLM, or of the EMT pathway, which are of pathophysiological importance, indicates that oxidative stress induces different transcriptional effects and outcomes in the two selected cell lines. In addition, expression levels and/or -direction of common genes were often different in HepG2 and Caco-2 cells, and this led to very diverse downstream effects as confirmed by correlating pathways to cell cycle changes. Altogether, this work contributes to obtaining a better molecular understanding of cell line-specific toxicity upon exposure to oxidative stress-inducing compounds.
\end{abstract}

(c) 2015 Elsevier Ltd. All rights reserved.

\section{Introduction}

Oxidative stress may occur in almost any tissue and is believed to play an important role in carcinogenesis. To sustain a proper regulation of biological processes, a physiological balance between the formation of reactive oxygen species (ROS) and the antioxidant network is essential (Forman et al., 2010; Sauer et al., 2001). Small amounts of ROS produced under normal physiological conditions have a protective role in the cell, however, overproduction may lead to accumulation in the intracellular environment resulting

Abbreviations: MTT, 3-(4,5-dimethylthiazol-2-yl)-2,5-diphenyltetrazolium bromide; DMPO, 5,5-dimethyl-1-pyrolline N-oxide; ARE, antioxidant response elements; CDF, chip definition files; DEGs, differentially expressed genes; DTW, dynamic time warping; EMT, epithelial-mesenchymal transition; ESR, electron spin resonance; FDR, false discovery rate; HCC, hepatocellular carcinoma; HCA, Hierarchical Clustering Analysis; IBD, inflammatory bowel disease; NER, nucleotid excision repair; ROS, reactive oxygen species; RMA, Robust Multi-array Average; STEM, Short Time-series Expression Miner.

* Corresponding author at: Department of Toxicogenomics, Faculty of Health, Medicine and Life Sciences, Maastricht University, Universiteitssingel 50, 6229 ER Maastricht, The Netherlands. Fax: +31 433884146.

E-mail address: 1.deferme@maastrichtuniversity.nl (L. Deferme). in oxidative stress, which subsequently leads to damage to various cell structures (Reuter et al., 2010). Spontaneous mutations that are then induced by oxidative stress may lead to carcinogenesis (Klaunig et al., 2010), and various cancers have been found to be in a constant state of oxidative stress, which suggests a role for oxidative stress in cancer promotion as well (Tudek et al., 2010). As portals of entry for xenobiotics, the liver and the gastrointestinal tract are continuously exposed to multiple chemicals, and as such are prone to oxidative damage induced by different types of oxidative compounds. As a consequence, the imbalance between ROS formation and antioxidant capacity in the colon and liver has been linked to increased cancer risk (Benhar et al., 2002). ROS-induced mechanisms have actually been related to different chronic liver diseases and hepatocellular carcinoma (HCC), and are induced by various risk factors for liver cancer such as hepatitis B and C or aflatoxin-B1 (Llovet et al., 2003). In addition, patients with inflammatory bowel diseases, accompanied by oxidative stress (Pavlick et al., 2002), are at increased risk for developing colorectal cancer (Itzkowitz and Yio, 2004).

Both liver and colon are equipped with defense mechanisms to limit oxidative stress induced damage. The nuclear factor E2-related 
factor 2 (NRF2) is a key regulator in the oxidative stress response and is expressed in a wide number of tissues, including liver and colon (Aleksunes and Manautou, 2007). Under non-stressful physiological condition, NRF2 is kept in the cytosol by KEAP1 (Sun et al., 2011). Oxidative stress may modify KEAP1 directly to cause their dissociation and consequently, NRF2 can escape proteosomal degradation and translocates to the nucleus to activate the antioxidant response element (ARE) which facilitates the transcriptional machinery in protecting the cell against oxidative stress (Kay et al., 2010). Glutathione biosynthesis is regulated by this cascade which activates its rate-limiting enzymes GCLC and GCLM and is believed to be involved in multiple liver diseases, as well as in chemo-resistance in HCC (Lu, 2013). Furthermore, nuclear factor- $\kappa \mathrm{B}(\mathrm{NF}-\kappa \mathrm{B})$ is translocated to the nucleus after induction by oxidative stress to activate genes involved in inflammation and immune responses, apoptosis and proliferation (Braun et al., 2006).

When these first line defense mechanisms fail in preventing oxidative stress-induced cellular damage, other processes such as DNA damage repair, cell cycle arrest or programmed cell death can be activated to prevent the formation of fixed mutations. However, when ROS levels are excessively elevated in cells, oxidative stress and consequently chronic inflammation will be induced. Attracted immune cells will constantly generate new ROS resulting in chronic oxidative stress which will induce fixed DNA mutations and will contribute to carcinogenesis by activating oncogenes and/ or inactivating tumor suppressor genes (Iwanaga et al., 2008; Kundu and Surh, 2012).

Where oxidative stress-related mechanisms described so far, seem to be quite generic, cell type-specific signaling pathways in cellular damage and carcinogenesis-induced by oxidative stress may underlie risks for chronic inflammation and carcinogenesis in particular target organs. For contributing to cancer prevention and treatment of tissue-specific cancers, it thus is of primary importance to investigate such cell type-specific differences at the molecular level. Since oxidative stress-related effects will differ in time, examining and comparing temporal changes in different cell types is of additional relevance. In previous in vitro studies, these oxidative stress-related mechanisms in response to different oxidants were extensively investigated using such a time series gene expression approach (Briede et al., 2010; Deferme et al., 2013). These cellular models readily allow for time-dependent analysis of whole genome gene expression, so here, we compare oxidant-induced gene expression changes and cell cycle distribution data from these previous performed in vitro studies in a human hepatoma cell line (HepG2 cells) and a human colon adenocarcinoma cell line (Caco-2 cells). Since both these cell lines respond to oxidative stress in activating antioxidant machineries (Briede et al., 2010; Deferme et al., 2013), are able to carry out biotransformation of xenobiotics and are permeable for different types of compounds (Artursson et al., 2001; Jennen et al., 2010), these cells are a convenient and reproducible in vitro alternative for in vivo toxicity testing. Both cell lines were exposed to menadione, a polycyclic aromatic quinone generating superoxide after redox cycling mediated by quinone oxidoreductase (NQO1), and $\mathrm{H}_{2} \mathrm{O}_{2}$ which can oxidize transition metals using the Fenton reaction to create hydroxyl radicals and is metabolized by catalase. Using a range of bioinformatics tools, unique and common genes/pathways will be identified as well as temporal expression profiles of differentially expressed genes (DEGs) investigated. In particular, oxidative stress-related pathways such as the NRF2/KEAP1 and the NF- $\kappa B$ pathway will be examined, since both regulate the transcription of a wide array of genes involved in the protection against different cell type-specific pathologies (Aleksunes and Manautou, 2007; Lee et al., 2005; Sun and Zhang, 2007). Therefore, it is of interest to investigate whether oxidative stress-induced transcription of these genes differs between different cell types.

\section{Material and methods}

\subsection{Cell culture}

HepG2 and Caco-2 cells (ATCC, LGC logistics, UK) were cultured in 6-well plates as previously described (Briede et al., 2010; Deferme et al., 2013). When cells were $80 \%$ confluent, the medium was replaced with medium containing $100 \mu \mathrm{M}$ menadione in both cell lines (Sigma-Aldrich, Zwijndrecht, The Netherlands) or $50 \mu \mathrm{M}$ $\mathrm{H}_{2} \mathrm{O}_{2} / \mathrm{Fe}^{2+}$ in HepG2 cells and $20 \mu \mathrm{M} \mathrm{H}_{2} \mathrm{O}_{2}$ in Caco- 2 cells (VWR int, UK). These non-cytotoxic concentrations were selected as previously described using MTT and ESR spectroscopy (Briede et al. 2010; Deferme et al., 2013). An exposure time series was applied in both cell lines $(0.5,1,2,4,8$ and $24 \mathrm{~h})$ and time-matched control cells (only medium) were treated in an identical manner without addition of oxidants.

\subsection{Cell cycle distribution}

Analyses of cell cycle profiles were performed as previously described (Staal et al., 2007). Cells were stained with propidium iodide and cell cycle profiles were analyzed using ModFit LT for Mac (version 2.0).

\subsection{Quantitative PCR and whole genome gene expression}

First RNA was extracted using QIAZOL in combination with MiRNeasy mini kits (Qiagen, Westburg, The Netherlands) and quality was assessed on an Agilent 2100 Bioanalyzer (Agilent Technologies, Amstelveen, The Netherlands) as previously described (Deferme et al., 2013).

Quantitative PCR was performed in biological duplicates for both treated and untreated HepG2/Caco- 2 cells and calculated as previously reported (Livak and Schmittgen, 2001; Staal et al., 2007) ( $n=2)$. RT-PCR was run on the MyiQ Single-Color RT-PCR Detection System (Bio-Rad Laboratories). Forward and reverse primers of Beta-Actin (used as reference), HMOX1, BCL2, GCLC, MAFG and NQO1 can be found in supplementary data 1 .

\subsubsection{Whole genome gene expression}

cRNA from treated and untreated HepG2 cells was prepared using Affymetrix synthesis and labeling kits as described before (Affymetrix, Santa Clara, CA) (Jennen et al., 2010). cRNA targets of control and exposed were individually hybridized on high-density oligonucleotide genetitan chips (Affymetrix Human Genome U133 Plus PM GeneTitan 24 arrays) as previously described (Deferme et al., 2013). Two oxidant exposures and time matched control samples during six different time points in biological triplicate $(n=3)$ resulted in a total of 72 single-color arrays.

Exposed and time matched control RNA samples from Caco-2 cells were two-color labeled and hybridized on the same array and scanned according to the manual for G4110B 22K/G4112F 44K Agilent Human Oligo Microarray (Agilent Technologies, Santa Clara, CA) as previously described (Briede et al., 2010). Two oxidant exposures and time matched control samples during six different time points in biological duplicates and technical duplicates (dye swap) resulted in a total of 48 two-color arrays.

\subsection{Re-annotation and normalization}

In HepG2 cells, data from 72 arrays were obtained, and Robust Multi-array Average (RMA) normalized and re-annotated to custom CDF files using the array analysis tool (http://arrayanalysis. org/). In Caco-2 cell, images of 48 hybridizations were processed with ImaGene 6.0 software (BioDiscovery Inc., Los Angeles, CA) to 
quantify spot signals and normalized in GeneSight software version 4.1.6 (BioDiscovery Inc.) as previously described (Briede et al., 2010). The data discussed in this publication have been deposited in NCBI's gene expression omnibus (Bruix et al., 2004; Quan et al., 2011): GSE39291: http://www.ncbi.nlm.nih.gov/geo/query/acc.cgi?acc=GSE39291, GSE15327: http://www.ncbi.nlm. nih.gov/geo/query/acc.cgi?acc=GSE15327.

\subsection{Data filtering and analysis}

Normalized datasets of both array platforms were compared, and only genes found on both types of array platforms (Agilent and Affymetrix) were selected. The intensities of the filtered data sets were $\log 2$ transformed, and subsequently, log ratios of treated versus controls were calculated. Differentially expressed genes (DEGs) for each experimental group were selected by using criteria that were described before (Deferme et al., 2013): (1) log ratio of $<-0.26$ or $>0.26$, (2) same direction for all replicates, (3) intensity of $\log 2$ values $>6$ for at least 2 out of 3 replicates, and (4) $p<0.05$. A gene was defined as being a DEG when it met all criteria, as described in material and methods, for at least one time point. The union of DEGs found after menadione and $\mathrm{H}_{2} \mathrm{O}_{2}$ exposure was used for further analysis (overlapping and unique DEGs between menadione and $\mathrm{H}_{2} \mathrm{O}_{2}$ ) and average $\log$ ratios were calculated.

\subsubsection{Data clustering}

DEGs induced by all compounds were clustered using the Hierarchical Clustering Analysis (HCA; Pearson correlation, Euclidean distance, pair wise complete distance) in GenePattern v.3.2.1 (http://genepattern.broadinstitute.org).

\subsubsection{Short Time-series Expression Miner (STEM)}

For identification of genes co-regulated time-dependently and clustering with the markers for oxidative stress, the software tool "Short Time-series Expression Miner" (STEM, version 1.1.2b; http://www.cs.cmu.edu/ jernst/stem/) (Ernst and Bar-Joseph, 2006) was used. Criteria used were described before (Briede et al., 2010). For correlation analysis, data from cell cycle distribution levels were transformed into $\log 2$ base ratios.

\subsubsection{Dynamic time warping (DTW)}

In order to explore cases where the time courses in the two organs were similar but not simultaneous, the DEGs were aligned using the matched functionality in dtw4omics (Cavill et al., 2013), an $\mathrm{R}$ package for dynamic time warping. To select those genes with significantly matching time courses a False Discovery Rate (FDR) of 5\% was applied.

\subsubsection{Pathway analysis}

MetaCore (GeneGo, San Diego, CA) was used to identify and visualize the involvement of the differentially expressed genes and transcription factors in the biological processes that may be affected at the level of pathways, by selecting significant pathways with a $p$ value $<0.05$ and false discovery rate (FDR) of $<5 \%$.

\section{Results}

\subsection{Comparison of oxidative stress-induced global gene expression changes in HepG2 and Caco-2 cells}

Time-dependent exposures to menadione and $\mathrm{H}_{2} \mathrm{O}_{2}$, in HepG2 and Caco-2 cells resulted in 72 and 48 raw transcriptomics data sets respectively conducted on two different array platforms as described in material and methods. In the MicroArray Quality Control (MAQC) project, intra- and interplatform data comparison was intensively studied and showed a high level of concordance and reproducibility within and between different platforms (MAQC_Consortium et al., 2006; Patterson et al., 2006). Raw expression values generated on different platforms cannot be directly compared because unique labeling methods which result in variable signals for probes that hybridize to the same target. Therefore, results obtained from both platforms were re-annotated, normalized and filtered in a similar manner and log ratios were calculated to obtain information in terms of differentially expressed genes (DEGs). In this way, we were certain that the following discussed differences between HepG 2 and Caco-2 cells were cell type-specific and not platform-specific. In addition, we analyzed basal gene expression in control samples and, since basal gene expression and active pathways, such as cell cycle, apoptotic and developmental processes, were primarily similar between HepG2 and Caco-2 cells, these differences/similarities resulted from a different response to oxidant exposure and cannot be assigned to basal gene expression differences.

\subsubsection{Single oxidant comparison}

HepG2 cells and Caco-2 cells were exposed to previously selected non-cytotoxic concentrations (Briede et al., 2010; Deferme et al., 2013) of two different oxidants, each producing a different oxygen radical, mainly superoxide anion produced by menadione, and hydroxyl radicals produced by $\mathrm{H}_{2} \mathrm{O}_{2}$. Transcriptomics data of both HepG2 and Caco-2 cells showed the expression of NQO1, responsible for reduction of menadione as well as catalase activity to metabolize $\mathrm{H}_{2} \mathrm{O}_{2}$ (Duthie and Collins, 1997). In addition, previously obtained ESR data (Briede et al., 2010; Deferme et al., 2013) showed the formation of comparable amounts of oxygen radicals in Caco-2 and HepG2 cells following exposure to menadione and $\mathrm{H}_{2} \mathrm{O}_{2}$. These results indicate that both cell lines were able to metabolize both compounds to produce ROS.

When comparing menadione exposure in both cell types, 1023 DEGs overlapped, 1351 DEGs were unique in HepG2 cells and 1369 DEGs were unique in Caco-2 cells. $\mathrm{H}_{2} \mathrm{O}_{2}$ exposure resulted in 159 overlapping DEGs between cell types, 111 unique DEGs in HepG2 cells, and 3127 unique DEGs in Caco-2 cells. Both overlapping and unique genes are involved in oxidative stress and DNA damage responses. To obtain a better understanding of global oxidative stress responses instead of specific effects of different reactive oxygen species, data sets of menadione and $\mathrm{H}_{2} \mathrm{O}_{2}$ were combined using the average expression of each gene in HepG2 and Caco-2 cells. Both overlapping and unique DEGs for both oxidants were included in further analysis.

\subsubsection{Global oxidative stress-induced changes in HepG2 and Caco-2 cells}

When comparing gene expression changes induced by oxidative stress in both cell types, a total of 1827 common and 3164 unique DEGs were found, whereof 637 unique genes in HepG2 and 2527 unique genes in Caco-2 cells as shown in Fig. 1A. The number of DEGs, either up- or downregulated, was lower in HepG2 cells at all measured time points. In addition, clustering of these overlapping genes showed that expression levels at early time points in Caco- 2 cells ( 0.5 and $1 \mathrm{~h}$ ) were more similar to expression levels at later time points in HepG2 cells ( 2 and $4 \mathrm{~h}$ ) (Fig. 1B). This shift was also observed in expression levels in HepG2 and Caco-2 cells at later time points and may indicate that comparable gene expression changes seem to appear earlier in Caco-2 cells.

\subsection{Oxidative stress affected genes and pathways in HepG2 and Caco- 2 cells}

The 1827 genes differentially expressed in both HepG2 and Caco- 2 cells included known oxidative stress-related genes such as CAT, OGG1, NRF2, NF- $\kappa B$, GCLC, AHR, HMOX1, GSR, GSTA1-4 

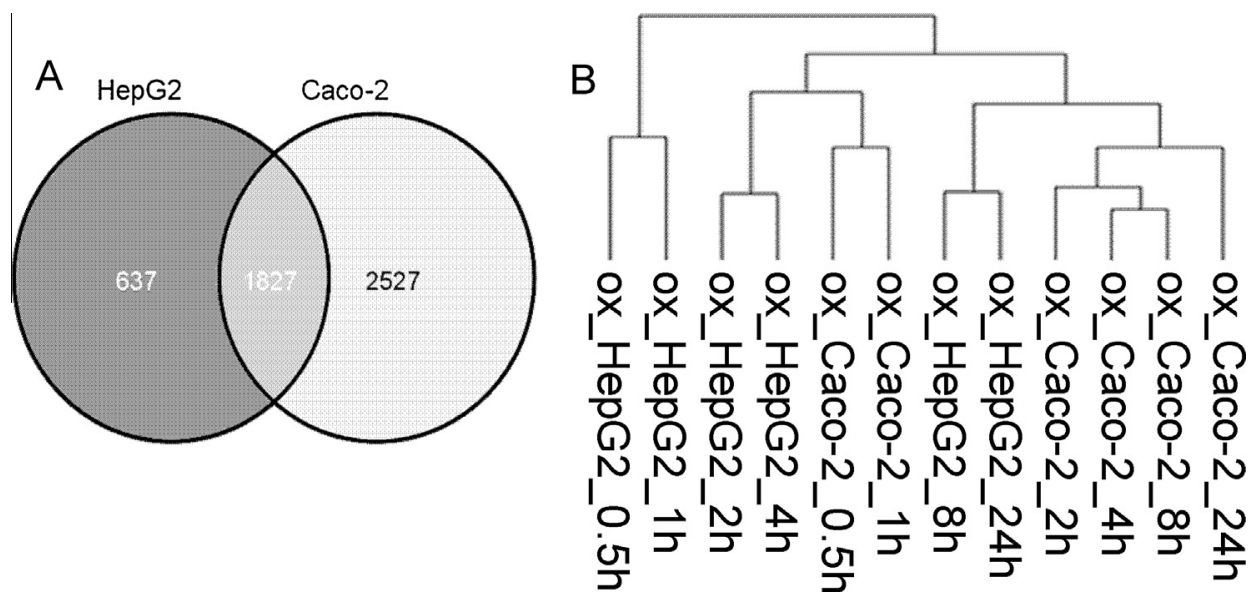

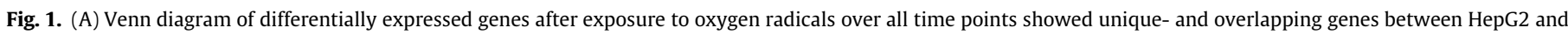

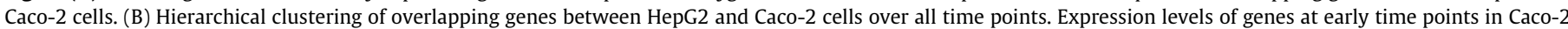

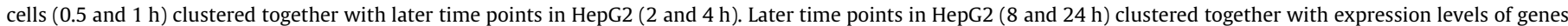
during 2-24 h exposure.

and MSH6. Interestingly, KEAP1, inhibitor of NRF2, was upregulated by oxidative stress only in HepG2 cells, as were Phase II gene GCLM and tumor suppressor gene PTEN which were up- and downregulated respectively. Unique genes in Caco-2 cells were among others involved in apoptosis and cell cycle, such as BAD, BCL2 and 3, PARP1 which were all downregulated, and CDKN1C and CDNK2D which were both upregulated. Also HMOX2 was significantly upregulated only in Caco-2 cells.

The 1827 overlapping genes were involved in a total of 75 significant pathways. Unique genes in HepG2 and Caco-2 genes were involved in 6 and 171 significant pathways respectively; the most significant pathways are shown in Table 1 . This difference in number of pathways is due to a higher number of unique DEGs found in Caco- 2 cells exposed to oxidative stress, which were consequently involved in more pathways. Overlapping pathways were especially involved in cell cycle processes, DNA damage and immune responses. Pathways most significantly affected and included in this overlap were chromosome condensation, nucleotide excision repair, WNT-, NOTCH1-, TGF-beta receptor- and p53 signaling. Pathways containing unique DEGs found in HepG2 cells are involved in calcium signaling, immune responses such as IL-7 signaling in $\mathrm{B}$ and $\mathrm{T}$ lymphocytes, and metabolic processes, while pathways comprising unique DEGs in HepG2 cells, are transcriptional silencing by HP1, induction of epithelial-mesenchymal transition (EMT) by TGF-beta and cytoskeletal remodeling. Pathways containing unique DEGs found in Caco-2 cells were especially involved in protein folding (POMC processing), oxidative phosphorylation and other pathways of EMT.

\subsection{Transcriptional regulation and downstream effects in HepG2 and Caco- 2 cells induced by oxidative stress}

32 commonly regulated transcription factors in HepG2 and Caco- 2 cells were identified, including oxidative stress-related factors such as NF- $\kappa B$, NRF2 and EGR1 (Table 2). In addition, AHR and MYC were also affected in both cell types, however, both these transcription factors were upregulated in HepG2 cells, and downregulated in Caco-2 cells.

Oxidative stress is known to activate important pathways such as the anti-oxidant NRF2/KEAP1 pathway and inflammatory
Table 1

(A) Significantly regulated pathways based on the overlapping genes, (B) unique genes in HepG2 cells and (C) unique genes in Caco- 2 cells. A summary of significantly $(p<0.05)$ regulated pathways and related cellular processes as indicated by MetaCore is shown.

\begin{tabular}{|c|c|}
\hline Pathways and cellular processes & $p$ value \\
\hline \multicolumn{2}{|l|}{ A. Overlapping pathways } \\
\hline \multicolumn{2}{|l|}{ Cell cycle and its regulation } \\
\hline Chromosome condensation in prometaphasis & $5.487 \mathrm{E}-12$ \\
\hline Transition and termination of DNA replication & $1.484 \mathrm{E}-08$ \\
\hline Initiation of mitosis & $3.383 \mathrm{E}-08$ \\
\hline \multicolumn{2}{|l|}{ DNA-damage response } \\
\hline ATM/ATR regulation of G1/S checkpoint & $1.063 \mathrm{E}-08$ \\
\hline Nucleotide excision repair & $1.457 \mathrm{E}-04$ \\
\hline \multicolumn{2}{|l|}{ Immune responses } \\
\hline IFN gamma signaling pathway & $1.683 \mathrm{E}-05$ \\
\hline Signaling pathway mediated by IL- 6 and IL-1 & $1.638 \mathrm{E}-04$ \\
\hline \multicolumn{2}{|l|}{ Apoptosis and survival } \\
\hline p53-dependent apoptosis & $7.108 \mathrm{E}-04$ \\
\hline Role of PKR in stress-induced apoptosis & $1.063 \mathrm{E}-03$ \\
\hline \multicolumn{2}{|l|}{ Development } \\
\hline WNT signaling pathway. Part 2 & $1.332 \mathrm{E}-05$ \\
\hline TGF-beta receptor signaling & $1.511 \mathrm{E}-04$ \\
\hline \multicolumn{2}{|l|}{ Signal transduction } \\
\hline AKT signaling & $1.540 \mathrm{E}-04$ \\
\hline JNK pathway & $2.366 \mathrm{E}-03$ \\
\hline PTEN pathway & $1.483 \mathrm{E}-02$ \\
\hline \multicolumn{2}{|l|}{ B. Unique pathways in HepG2 cells } \\
\hline \multicolumn{2}{|l|}{ Transcription } \\
\hline Role of HP1 family in transcriptional silencing & $5.631 \mathrm{E}-06$ \\
\hline TGF-beta-dependent induction of EMT via RhoA, PI3K and ILK & $4.517 \mathrm{E}-04$ \\
\hline \multicolumn{2}{|l|}{ Cytoskeletal remodeling } \\
\hline CDC42 in cellular processes & $9.228 \mathrm{E}-05$ \\
\hline \multicolumn{2}{|l|}{ Cell cycle } \\
\hline The metaphase checkpoint & $1.139 \mathrm{E}-04$ \\
\hline Start of DNA replication in early S phase & $5.909 \mathrm{E}-04$ \\
\hline \multicolumn{2}{|l|}{ C. Unique pathways in Caco-2 cells } \\
\hline \multicolumn{2}{|l|}{ Protein folding and maturation } \\
\hline POMC processing & $1.368 \mathrm{E}-11$ \\
\hline Bradykinin/Kallidin maturation & $8.354 \mathrm{E}-04$ \\
\hline \multicolumn{2}{|l|}{ Cytoskeleton remodeling } \\
\hline TGF, WNT and cytoskeletal remodeling & $3.154 \mathrm{E}-09$ \\
\hline Role of PKA in cytoskeleton reorganisation & $1.091 \mathrm{E}-05$ \\
\hline \multicolumn{2}{|l|}{ Others } \\
\hline Oxidative phosphorylation & $7.302 \mathrm{E}-10$ \\
\hline Some pathways of EMT in cancer cells & $3.214 \mathrm{E}-07$ \\
\hline
\end{tabular}


Table 2

Common transcription factors found in the 1827 overlapping DEGs of HepG2 and Caco- 2 cells and their overall expression direction over time.

\begin{tabular}{|c|c|c|c|}
\hline \multicolumn{2}{|c|}{ Common transcription factors in HepG 2 and Caco- 2 cells } & \multicolumn{2}{|c|}{$\begin{array}{l}\mathrm{Up}(\uparrow) / \text { down }(\downarrow) \\
\text { regulated }\end{array}$} \\
\hline TF & Full name & HepG2 & Caco-2 \\
\hline AHR & Aryl hydrocarbon receptor & $\uparrow$ & $\downarrow$ \\
\hline AP3M1 & $\begin{array}{l}\text { Adaptor-related protein complex } 3 \text {, mu } 1 \\
\text { subunit }\end{array}$ & $\downarrow$ & $\uparrow$ \\
\hline ATF3 & Activating transcription factor 3 & $\uparrow$ & $\uparrow$ \\
\hline CEBPA & CCAAT/enhancer binding protein (C/EBP), alpha & $\downarrow$ & $\downarrow$ \\
\hline CEBPB & CCAAT/enhancer binding protein (C/EBP), beta & $\uparrow$ & $\downarrow$ \\
\hline CEBPD & CCAAT/enhancer binding protein (C/EBP), delta & $\downarrow$ & $\downarrow$ \\
\hline CITED2 & $\begin{array}{l}\mathrm{Cbp} / \mathrm{p} 300 \text {-interacting transactivator, with Glu/ } \\
\text { Asp-rich carboxy-terminal domain, } 2\end{array}$ & $\downarrow$ & $\downarrow$ \\
\hline E2F3 & E2F transcription factor 3 & $\downarrow$ & $\downarrow$ \\
\hline EGR1 & Early growth response 1 & $\uparrow$ & $\downarrow$ \\
\hline ETS2 & $\begin{array}{l}\text { v-ets erythroblastosis virus E26 oncogene } \\
\text { homolog } 2\end{array}$ & $\uparrow$ & $\downarrow$ \\
\hline FOSL1 & FOS-like antigen 1 & $\uparrow$ & $\uparrow$ \\
\hline FOXA1 & Forkhead box A1 & $\downarrow$ & $\downarrow$ \\
\hline FOXA2 & Forkhead box A2 & $\downarrow$ & $\downarrow$ \\
\hline FOXA3 & Forkhead box A3 & $\downarrow$ & $\uparrow$ \\
\hline FOXM1 & Forkhead box M1 & $\downarrow$ & $\downarrow$ \\
\hline JUN & jun oncogene & $\uparrow$ & $\uparrow$ \\
\hline JUNB & jun B proto-oncogene & $\uparrow$ & $\uparrow$ \\
\hline JUND & jun D proto-oncogene & $\uparrow$ & $\downarrow$ \\
\hline KLF6 & Kruppel-like factor 6 & $\uparrow$ & $\downarrow$ \\
\hline MAFG & $\begin{array}{l}\text { v-maf musculoaponeurotic fibrosarcoma } \\
\text { oncogene homolog G }\end{array}$ & $\uparrow$ & $\downarrow$ \\
\hline MAFK & $\begin{array}{l}\text { v-maf musculoaponeurotic fibrosarcoma } \\
\text { oncogene homolog } \mathrm{K}\end{array}$ & $\uparrow$ & $\uparrow$ \\
\hline MYC & $\begin{array}{l}\text { v-myc myelocytomatosis viral oncogene } \\
\text { homolog }\end{array}$ & $\uparrow$ & $\downarrow$ \\
\hline NFE2L2 & Nuclear factor (erythroid-derived 2)-like 2 & $\uparrow$ & $\uparrow$ \\
\hline NF-KB & $\begin{array}{l}\text { Nuclear factor of kappa light polypeptide gene } \\
\text { enhancer in B-cells } 1\end{array}$ & $\downarrow$ & $\downarrow$ \\
\hline NR2F2 & $\begin{array}{l}\text { Nuclear receptor subfamily } 2 \text {, group F, member } \\
2\end{array}$ & $\downarrow$ & $\downarrow$ \\
\hline NR3C1 & $\begin{array}{l}\text { Nuclear receptor subfamily } 3 \text {, group C, member } \\
1 \text { (glucocorticoid receptor) }\end{array}$ & $\uparrow$ & $\downarrow$ \\
\hline NR4A1 & $\begin{array}{l}\text { Nuclear receptor subfamily } 4 \text {, group A, member } \\
1\end{array}$ & $\uparrow$ & $\downarrow$ \\
\hline SMAD3 & SMAD family member 3 & $\uparrow$ & $\downarrow$ \\
\hline SREBF1 & $\begin{array}{l}\text { Sterol regulatory element binding transcription } \\
\text { factor } 1\end{array}$ & $\downarrow$ & $\uparrow$ \\
\hline STAT6 & $\begin{array}{l}\text { Signal transducer and activator of transcription } \\
6 \text {, interleukin- } 4 \text { induced }\end{array}$ & $\uparrow$ & $\uparrow$ \\
\hline TEAD4 & TEA domain family member 4 & $\uparrow$ & $\uparrow$ \\
\hline XBP1 & $\mathrm{X}$-box binding protein 1 & $\downarrow$ & $\downarrow$ \\
\hline
\end{tabular}

pathways regulated by NF- $\kappa \mathrm{B}$. Therefore, an oxidative stress-regulated effect on these pathways in both cell types is visualized in Fig. 2. NRF2 is upregulated in both cell types, however, stronger induced in Caco-2 cells where Keap1 is not differentially expressed (Fig. 2B). In addition, the downstream Phase II gene, GCLM, is also not differentially expressed in Caco-2 cells. Upstream activators of NRF2, ERK and JNK, are significantly downregulated in Caco-2 cells and were not affected in HepG2 cells. Interestingly, NF- $\kappa$ B was significantly downregulated at $24 \mathrm{~h}$ in both cell types (Fig. 2). However, downstream genes of NF- $\kappa \mathrm{B}$, such as BCL2, TLR2 and ICAM1, were differently expressed in Caco-2, while only expression of ICAM1 was affected in HepG2 cells.

\subsubsection{Validation using quantitative $P C R$}

Micro-array detected changes in expression levels for the oxidative stress responsive genes, SOD1, SOD2, CAT and P21 were validated as published before (Briede et al., 2010; Deferme et al., $2013)$. Additionally, expression levels of HMOX1 $(R>0.9)$, NQO1 $(R>0.9)$, BCL2 $(R>0.9)$, GCLC $(R>0.9)$ and MAFG $(R>0.78)$, observed by micro-array, highly correlated with expression levels determined by qPCR (supplementary data 2).
3.4. Comparison of phenotypical anchoring between transcriptomics and cell cycle changes in HepG2 and Caco-2 cells

To obtain more information how HepG2 and Caco-2 cells differ in functional responses toward oxidative stress, data from cell cycle distribution by oxidant exposure was (Briede et al., 2010; Deferme et al., 2013) correlated to gene expression changes over time using STEM analysis.

Correlations between changes in the G1, S and G2 phase of the cell cycle induced by oxidative stress in HepG 2 and Caco- 2 cells, and transcriptomics changes provided a significant number of genes that correlated to the $S$ phase in both cell types, and to the G1 phase in Caco-2 cells and the G2 phase in HepG2 cells. However, gene expression changes correlating to these cell cycle phases were entirely different between HepG2 and Caco-2 cells. Genes correlating to cell cycle changes were mainly involved in cell cycle processes, immune responses, transcription and metabolism of different amino acids and apoptosis and survival pathways as shown in Table 3. In more detail, the percentages of HepG2 cells present in the $S$ phase during oxidative stress decreased after $24 \mathrm{~h}$ (Fig. 3) and correlated with downregulated expression of CDK1, CDK3 and CCNB2, all well described genes in the cell cycle machinery. These correlating genes were mainly involved in pathways such as the initiation of mitosis, and chromosome condensation in prometaphasis (Table 3 ). On the other hand, the percentage of Caco-2 cells during this stage of the cell cycle was increased (Fig. 3) and correlated significantly to upregulated genes involved in IL-1 signaling and transcriptional regulation of aminoacid metabolism (Table 3 ). In addition, the percentage of Caco- 2 cells in the G1 phase was reduced after $24 \mathrm{~h}$ indicating an S phase arrest following oxidative stress (Fig. 3). This change in cell cycle distribution correlated with downregulated genes involved in leucin and valine metabolism, but also chromosome condensation as indicated in Table 3. The increased percentage of HepG2 cells in G2 phase following oxidative stress (Fig. 3) correlated to upregulated genes involved in programmed cell death by ceramides and ERK activation (Table 3 ).

These results indicated that cell cycles of HepG2 and Caco-2 cells were differently regulated in response to oxidative stress. This was mainly observed by the fact that pathways correlating to cell cycle changes induced by oxidative stress were entirely different between HepG2 and Caco-2 cells.

\subsection{Temporal gene expression analysis between HepG2 and Caco-2 cells following oxidative stress}

Using STEM, each gene was assigned to the model profile which its temporal expression profile most closely matched, based on the correlation coefficient. In this study, oxidative stress in HepG 2 cells resulted in 2464 DEGs that were assigned to 8 significant time profiles, whereas exposure in Caco-2 cells resulted in 4354 DEGs that were assigned to 11 significant time profiles. Five identical time profiles between both cell models were identified as visualized in Fig. 4. This means that genes assigned to these time clusters follow a similar expression profile over time in both cell lines. Three of these clusters (1, 2 and 5) contain genes that were downregulated over time, and two clusters ( 3 and 4 ) contain only genes which were upregulated over time. Interestingly, the oxidative stress-related genes CAT, HMOX1 and GCLC follow a similar expression profile over time in both cell types. Expression of CAT is downregulated over time (Fig. 4, cluster 2), whereas HMOX1 and GCLC are similar upregulated over time as also observed in Fig. 2 (Fig. 4, cluster 4). In contrast, BIK and JUN were upregulated over time in HepG2 cells (Fig. 4, cluster 4) and at the same time downregulated in Caco-2 cells (Fig. 4, cluster 5). In addition, expression of transcription factors NF- $\mathrm{KB}$ and NRF2 decreases over time in both cell types, 

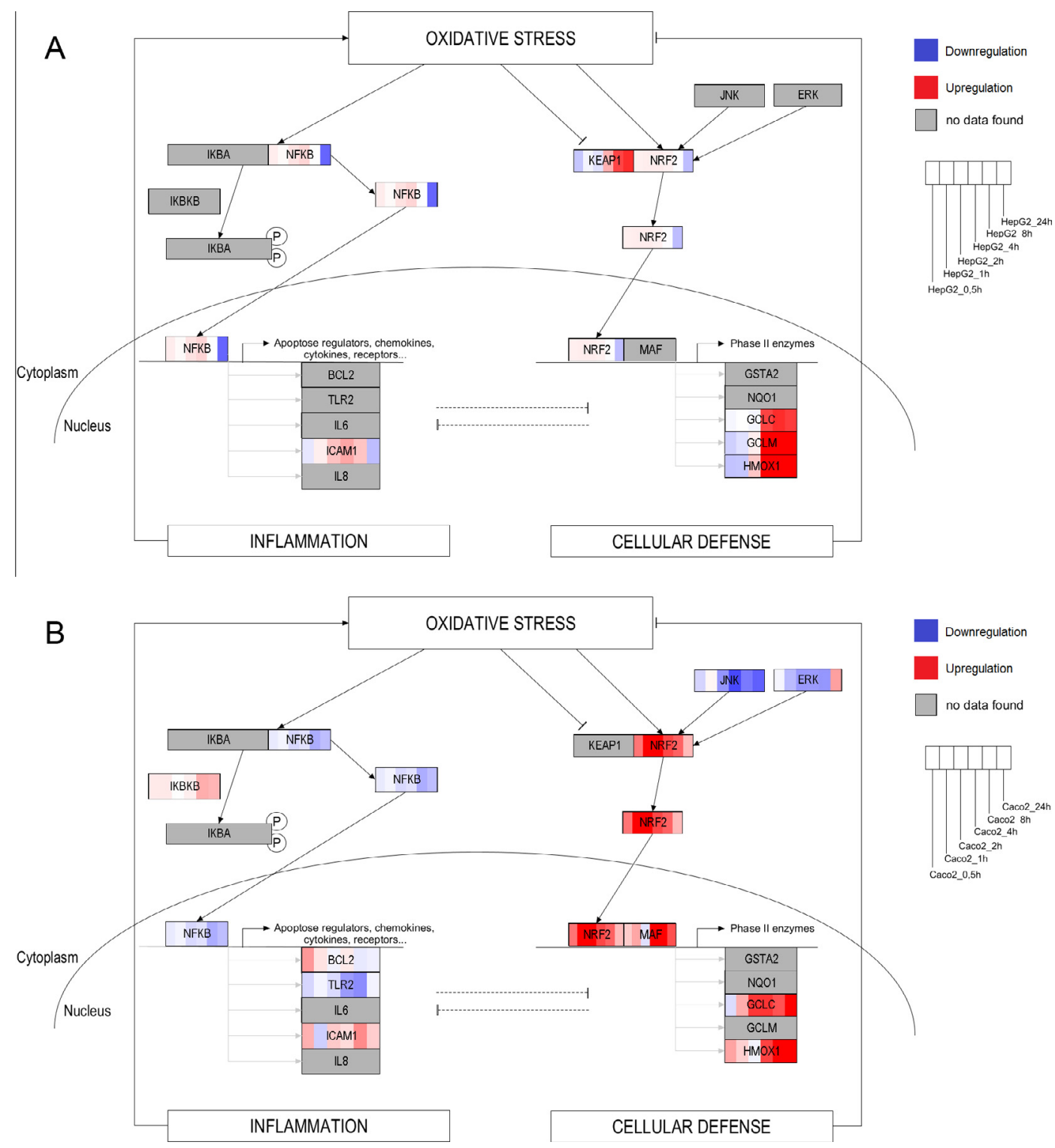

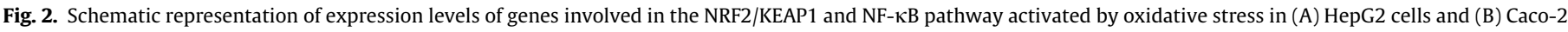

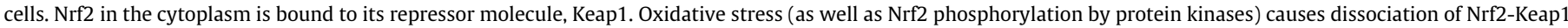

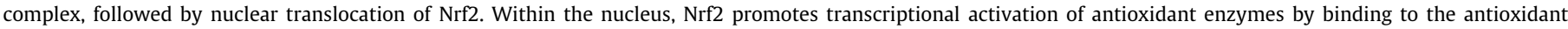

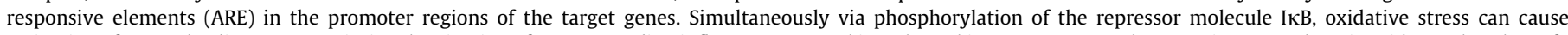

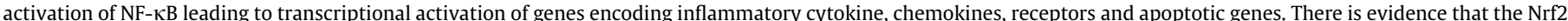

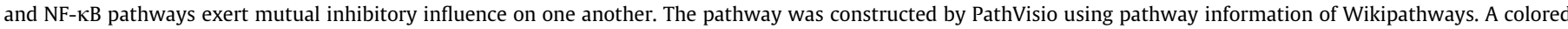

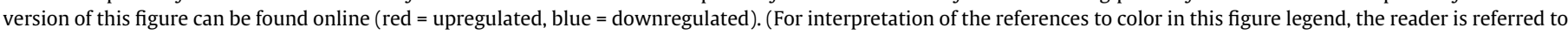
the web version of this article.)

however following a different expression profile during oxidative stress. Pathway analysis of genes that were assigned to these clusters (Fig. 4) is presented in Table 4. Overlapping pathways such as NER in DNA damage, WNT signaling and chromosome condensation in prometaphase (Table $4 \mathrm{~A}$ ) were found to contain genes that were downregulated over time. In contrast, genes involved in overlapping pathways such as IL13 signaling and MIF-induced cell adhesion were found to be upregulated over time. As previously mentioned, we found that oxidative stress results in more cell-specific than commonly differentially expressed genes over time and consequently led to more unique than shared time related pathways. For example, at the moment that cell cycle and DNA damage pathways are regulated in HepG2 cells, immune and apoptotic pathways are regulated in Caco- 2 cells (Table 4B and C).
In addition, dynamic time warping (DTW) was used to find comparable changes in gene expression that do not occur simultaneously (Cavill et al., 2013). Only 58 significant associations were found between HepG 2 and Caco-2 cells, what again indicates more differences than similarities between both these cell types. 16 genes were involved in responses to chemical stimuli and 3 genes in glutathione transferase. Oncogene ERBB2 was found to have a similar expression profile in HepG2 and Caco-2 cell with a delay in HepG2 cells. GSTA4, a gene involved in glutathione transferase showed also a similar expression profile in HepG2 and Caco-2 cells, however, this profile had a delay in Caco-2 cells. The opposite was found for MGST2 which peaked earlier in Caco-2 cells, resulting in different effects within the glutathione transferase pathway in HepG2 and Caco-2 cells, which will lead to differences in the defense to cellular oxidative stress by glutathione. 
Table 3

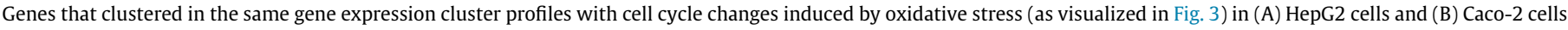
using STEM. Significant $(p<0.05)$ pathways as indicated by MetaCore.
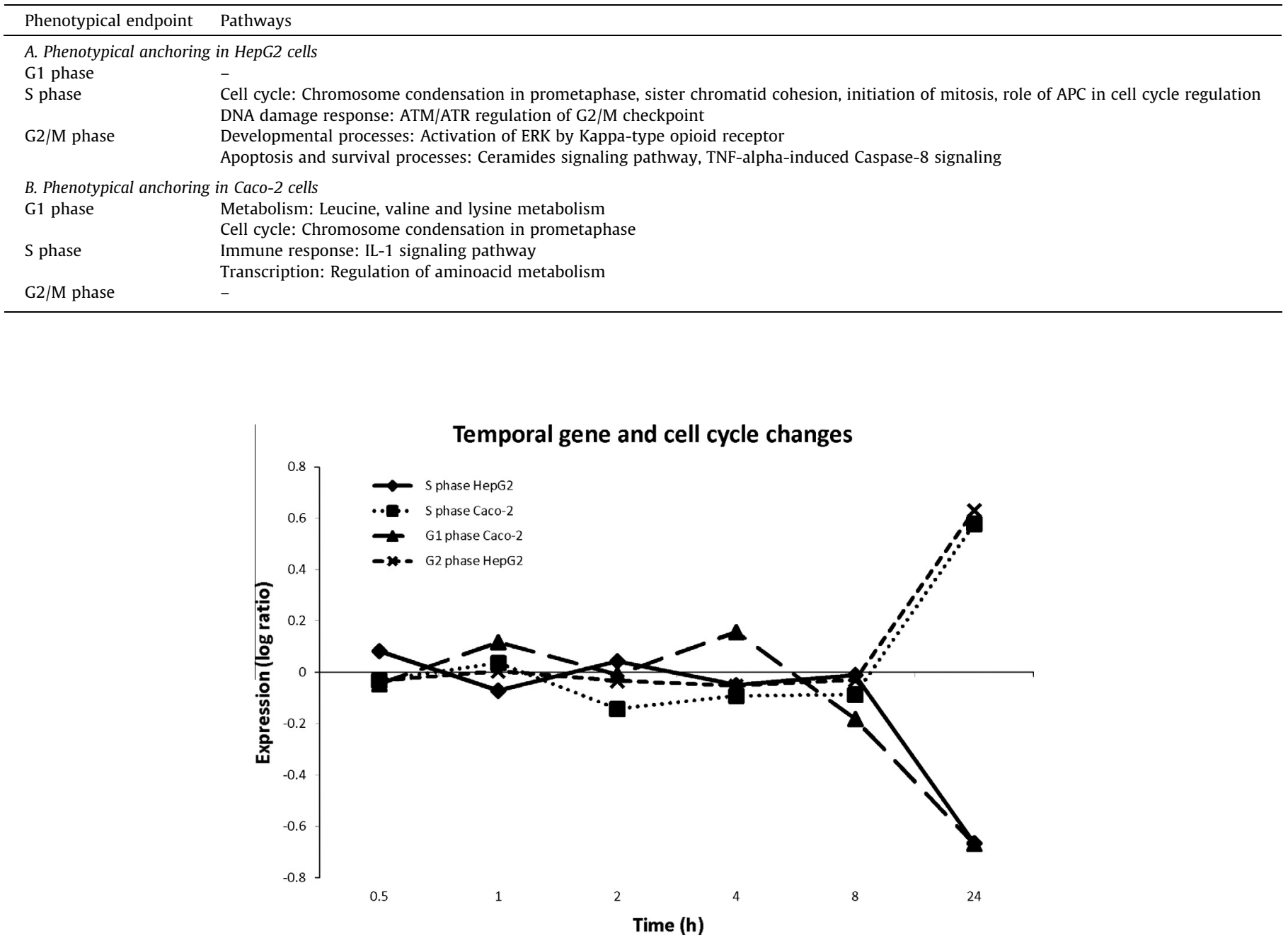

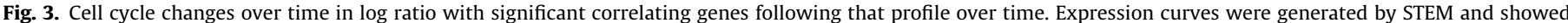

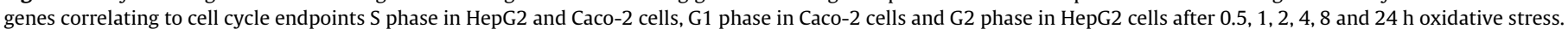

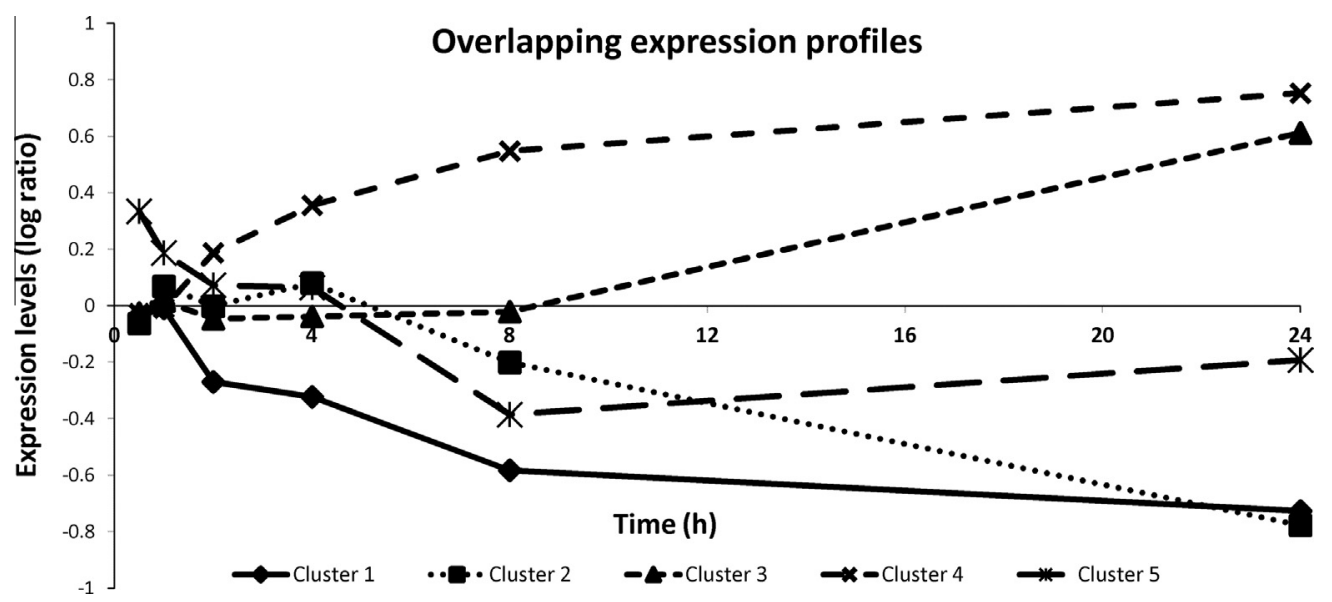

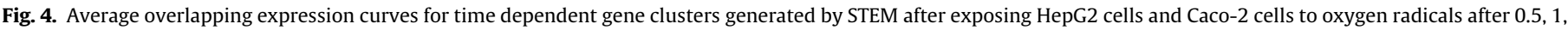
2, 4, 8 and 24 h. Pathways were defined for genes present in these temporal expression curves and can be found in Table 4 . 
Table 4

(A) Significantly regulated pathways based on (A) overlapping genes, (B) unique genes in HepG2 cells and (C) unique genes in Caco-2 cells. A summary of significantly $(p<0.05)$ regulated pathways as indicated by MetaCore is shown.

\begin{tabular}{|c|c|}
\hline Pathways & Cluster $^{a}$ \\
\hline \multicolumn{2}{|l|}{ A. Overlapping pathways } \\
\hline Chromosome condensation in prometaphasis & 1 \\
\hline Nucleotide excision repair & 1 \\
\hline WNT signaling pathway. Part 2 & 1 \\
\hline IFN gamma signaling pathway & 1 \\
\hline Butanoate, Lysine, Propionate and Tryptophan metabolism & 2 \\
\hline IL-13 signaling via PI3K-ERK & 3 \\
\hline MIF-induced cell adhesion, migration and angiogenesis & 4 \\
\hline TGF-beta-dependent induction of EMT via MAPK & 5 \\
\hline IL-17 signaling pathways & 5 \\
\hline \multicolumn{2}{|l|}{ B. Unique pathways in HepG2 cells } \\
\hline Transition and termination of DNA replication & 1 \\
\hline Start of DNA replication in early $S$ phase & 1 \\
\hline Mismatch repair & 1 \\
\hline AKT signaling & 1 \\
\hline Bile acids regulation of glucose and lipid metabolism via FXR & 2 \\
\hline Role of IL- 8 in angiogenesis & 2 \\
\hline NOTCH1-mediated pathway for NF-KB activity modulation & 2 \\
\hline P53 signaling & 2 \\
\hline Activation of ERK by Kappa-type opioid receptor & 3 \\
\hline Ceramides signaling pathway & 3 \\
\hline IL-1, CD28, CD16 and IL-2 signaling & 4 \\
\hline TGF-beta receptor signaling & 4 \\
\hline Brca1 as a transcription regulator in DNA damage & 5 \\
\hline \multicolumn{2}{|l|}{ C. Unique pathways in Caco-2 cells } \\
\hline Cytoskeleton remodeling & 1 \\
\hline IL-2 activation and signaling pathway & 1 \\
\hline Role of IL-8 in angiogenesis & 1 \\
\hline BAD phosphorylation & 1 \\
\hline CCR4-induced chemotaxis of immune cells & 2 \\
\hline IL-1, IL-15, IL-12 and IL-17 signaling & 3 \\
\hline AKT signaling & 3 \\
\hline Start of DNA replication in early $S$ phase & 4 \\
\hline NGF activation of NF-kB & 5 \\
\hline IL-1, IL-18, IL-22, IL-12, IL-10 and IL-15 signaling & 5 \\
\hline P53 signaling & 5 \\
\hline
\end{tabular}

a Defined cluster as presented in Fig. 4.

\section{Discussion}

Correspondences and differences between HepG2 and Caco-2 cells were evaluated during multiple time points $(0.5,1,2,4,8$ and $24 \mathrm{~h}$ ) to improve our knowledge of cell type-specific effects of oxidative stress and its effects on transcriptomics. We identified processes that are significantly regulated as a general response toward oxidative stress in both HepG2 and Caco-2 cells. However, the main new finding of this work is the presence of unique cell-specific transcriptome responses following oxidative challenge. Differences in such cell type-specific expression profiles have previously been observed (Hollensworth et al., 2000; Jarrett et al., 2006; Malik et al., 2014; Tilton et al., 2014), however, how the complete transcriptome of different cell types responds to oxidative stress has not been described before.

Although different array platforms were used, it has been described that high levels of concordance and reproducibility between different platforms (MAQC_Consortium et al., 2006; Patterson et al., 2006) exist when handling the data in a similar manner. Data from menadione and $\mathrm{H}_{2} \mathrm{O}_{2}$ exposure in HepG2 and Caco- 2 cells were combined to evaluate global oxidative stress responses on a molecular level. Multiple studies using cDNA arrays to study such oxidative stress-related mechanisms in different cell models, exist. By identifying specific gene signatures of disease, they provided us with molecular evidence that oxidative stress is linked with hepatotoxicity and HCC (Beltran-Ramirez et al., 2010; Fredriksson et al., 2014; Liu et al., 2011) as well as inflammatory bowel disease and colon cancer (Hebels et al., 2010; Ijssennagger et al., 2013). These studies describe the involvement of different signal transduction pathways including NRF2/KEAP1, NF- $\kappa$ B, TNF-alpha, different map kinases and glutathione signaling in the response toward oxidative stress in models of both liver and colon (Aravinthan et al., 2014; Beltran-Ramirez et al., 2010; Fredriksson et al., 2014; Hebels et al., 2010; Huo et al., 2014) which were also described in our study. The designs of these studies are very diverse ranging from exposing rodents or different cell models to compounds such as Aflatoxin B1, Copper, Diclofenac and nitrosamines to basal expression levels of HCC and colon cancer patients. We, however, found a single dataset from HepG2 cells challenged with $\mathrm{H}_{2} \mathrm{O}_{2}$ using a study design similar to our data (Aravinthan et al., 2014). These authors identified an oxidative stress-related senescent signature of 354 DEGs of which 86 DEGs overlapped with our data set, including upregulation of cell cycle-related genes and transcription factors such as AHR, NF- $\kappa B$ and TGF-beta which may result in impaired signal transduction. Overall, their results confirm the hypothesis that oxidative stress plays an important role in the onset of liver disease, however, it remains unclear how these specific gene expression responses toward oxidative stress can differ between cell types. In addition, in this study, a much higher dose $(0.5 \mathrm{mM}$ versus $0.05 \mathrm{mM})$ during only a single time point $(1 \mathrm{~h})$ was used, which made it impossible to include this data into our time dependent comparative analysis. In general, the absence of comparable data implies that our work presents novel information regarding cell line specific gene expression responses.

Approximately, 3100 differences and 1800 overlaps in gene expression were evident between HepG2 and Caco-2 cells upon challenge by oxidative stressors. Despite the higher number of differently expressed than overlapping genes, most oxidative stressrelated genes such as CAT, HMOX1 and GCLC were differentially expressed in both cell types. NRF2 has a central role in this response toward oxidative stress and it has been shown that the antioxidant response is a multi-organ protective mechanism (Chan et al., 2001; Lee et al., 2003, 2005; Ramos-Gomez et al., 2003; Rangasamy et al., 2004). Several studies have demonstrated that NRF2 activation is a critical regulator of phase 2 gene expression by binding to ARE (Anwar-Mohamed et al., 2011; Jin et al., 2014; Limonciel et al., 2015; Ramos-Gomez et al., 2001). The subsequent increased expression of antioxidant genes appears different in each organ (Lee et al., 2005). Moreover, NRF2-target genes that support the integrity of a specific organ were selectively regulated in combination with cell type-specific pathways (Lee et al., 2005). In our study, expression of NRF2 was also upregulated following oxidative stress in both HepG2 and Caco-2 cells, however, expression levels differed over time. These increased levels of NRF2 expression are observed to be dynamic and decrease after prolonged oxidant challenge in both cell types, suggesting that a negative feedback is activated to normalize its expression.

NRF2 can be activated directly by oxidative stress (D'Autreaux and Toledano, 2007) or by map kinases such as ERK, JNK, PKC and PI3K/AKT which also activate NRF2 by inhibiting binding of KEAP1 (Ganan-Gomez et al., 2013). Pathway analysis shows that during oxidative stress, genes involved in PI3K/AKT signaling are modified in Caco- 2 cells and genes involved in PKC signaling are upregulated in HepG2 cells. Such cell type-specific activation of these signaling pathways was described before in breast- and colon-derived cell lines, where colon cells did also show AKT activation following exposure to nanoparticles (Rauch et al., 2012). However, a detailed analysis of the proteome and intracellular levels of protein kinases is necessary to validate the activation of NRF2 and these different signaling pathways in HepG2 and Caco2 cells, and is therefore an important element for future studies.

$\mathrm{NF}-\kappa \mathrm{B}$ was also negatively regulated following $24 \mathrm{~h}$ of oxidative challenge, however, different expression levels over time were 
observed between HepG2 and Caco-2 cells. Oxidative stress-regulated activation of NF- $\kappa \mathrm{B}$ can be cell type-specific and might differ over time (Nakajima and Kitamura, 2013). In addition, oxidative stress can inhibit basal NF- $\mathrm{B}$ expression, possibly by oxidation of IKK or downregulation of AKT (Franke et al., 1997; Xie and Shaikh, 2006), however these mechanisms cannot be confirmed by our transcriptomics data. A potential cross-talk between oxidative stress regulated NF- $\kappa B$ and NRF2 activation as have been investigated can be an alternative mechanism (Fig. 2), suggesting HMOX1 upregulation by NRF2 as a key player in inhibiting the inflammatory effects of NF- $\kappa \mathrm{B}$ (Banning and Brigelius-Flohe, $2005)$. On the contrary, it is believed that NF- $\kappa B$ could directly inhibit NRF2 activity at the transcription level (Liu et al., 2008). Our results show that a higher expression of HMOX1 is associated with a lower NF- $\kappa B$ expression, supporting the hypothesis of an anti-inflammatory effect of NRF2.

An important difference is that expression levels and/or direction of overlapping genes were mostly not similar in the two cell types. For example, the 0.5 and $1 \mathrm{~h}$ time point in Caco- 2 cells clustered with the 2 and $4 \mathrm{~h}$ time point of HepG2 cells, indicating a slower metabolic rate in this liver carcinoma cell line. However, DTW showed genes, such as glutathione s-transferase A4 (GSTA4), important in oxidative stress protection, with a delayed expression profile in Caco-2 cells, indicating differences in transcriptional regulation and not in metabolic rate between these cell lines. In addition, expression of AHR and MYC in Caco-2 cells was downregulated in response to oxidative stress, while, at the same time, they were upregulated in HepG2 cells following oxidant exposure. Upregulation of AHR expression was also observed in the study of Aravinthan et al. (2014) using HepG2 cells challenged with $\mathrm{H}_{2} \mathrm{O}_{2}$. In a study of Liu et al. (2013), results indicate that AHR upregulation is associated with hepatic tumor invasion, where on the contrary, a recent study of Furumatsu et al. (2011) shows that AHR activation has a protective role in IBD, and downregulation can aggravate colitis, which is one of the main risk factors in the development of colon cancer (Grivennikov, 2013). Changes in MYC expression on the other hand can have very different cellular outcomes, since it regulates $15 \%$ of all genes (Kim et al., 2008). These differences in expression direction and affected genes between HepG2 and Caco-2 cells indicate a cell-specific response to oxidative stress, which may lead to very diverse downstream effects. This may be an explanation for the high number of unique affected genes between HepG2 and Caco- 2 cells. In addition, these cell-specific responses can also be translated to differences in antioxidant mechanisms, DNA damage responses, inflammatory responses and cell cycle changes. This was confirmed by the observation that cell cycle changes in HepG2 cells were different compared to Caco-2 cells and correlated with apoptotic pathways whereas cell cycle changes in Caco-2 cells correlated with immune responses and metabolism. This indicates that oxidative stress induces cellular damage that differs between cell types and can lead to a very different cell fate.

Next to these cell-specific responses following oxidative stress, different pathways are found to be similarly affected in both HepG 2 and Caco- 2 cells. Interestingly, the WNT signaling pathway is significantly changed in both cell lines and involved genes do also follow the same expression profile over time. WNT signaling has been described as being a key player in the development of colon cancer (Gmeiner et al., 2008), but is also involved in hepatocellular carcinoma (Pez et al., 2013). Also cellular processes such as cell cycle- and DNA damage responses, including chromosome condensation and NER, were similarly downregulated over time in HepG2 and Caco-2 cells. P53 signaling, an important tumor suppressor gene, was downregulated in both cell types, however, following a different temporal expression profile. Pathways such as calcium signaling, HP1 induced transcriptional silencing and
EMT induction by TGF-beta, on the other hand, seems to be HepG2 cell-specific in response to oxidative stress. Protein folding, oxidative phosphorylation and different pathways of EMT were more Caco-2 cell-specific responses to oxidative stress. EMT is an important step in tumor progression and has been linked to chronic inflammation and oxidative stress (Giannoni et al., 2012; Wang et al., 2010), however, cell type-specific induction of EMT after oxidative stress has not been investigated yet. In addition to these findings, results showed significant pathways containing unique and overlapping DEGs, indicating that similar pathways were affected in both cell types, however, by affecting different genes in a particular pathway.

In conclusion, by comparing transcriptomics data of HepG2 and Caco- 2 cells exposed to oxidants, more differences than common genes and pathways were identified, possibly due to differences in transcriptional regulation or cell type-specific genotype. First response pathways to oxidative stress were similar in both cell types, however, the presence of cell specific pathways, which are of pathophysiological importance, indicates that oxidative stress induces different effects and outcomes in different cell types. Furthermore, time related events after oxidative stress differ between HepG 2 and Caco-2 cells, indicating a cell type-specific regulatory response to oxidants, leading to different downstream effects and cascade signaling. Combining this with differences in transcriptional expression over time, this work provided us with novel molecular knowledge of generic and cell type-specific gene expression induced by oxidative stress. These results may contribute to a better understanding of how these mechanisms might be involved in oxidative stress-induced cell toxicity and their possible involvement in colon in and liver cancer initiation and progression.

\section{Funding information}

N/A.

\section{Conflict of Interest}

The authors declare that there are no conflicts of interest.

\section{Transparency Document}

The Transparency document associated with this article can be found in the online version.

\section{Acknowledgement}

The authors would like to thank D. Jennen for his help with data analysis and obtaining the correct data.

\section{Appendix A. Supplementary material}

Supplementary data associated with this article can be found, in the online version, at http://dx.doi.org/10.1016/j.tiv.2015.03.007.

\section{References}

Aleksunes, L.M., Manautou, J.E., 2007. Emerging role of Nrf2 in protecting against hepatic and gastrointestinal disease. Toxicol. Pathol. 35, 459-473.

Anwar-Mohamed, A., Degenhardt, O.S, El Gendy, M.A., Seubert, J.M., Kleeberger, S.R., El-Kadi, A.O., 2011. The effect of Nrf2 knockout on the constitutive expression of drug metabolizing enzymes and transporters in $\mathrm{C} 57 \mathrm{Bl} / 6$ mice livers. Toxicol. In Vitro 25, 785-795.

Aravinthan, A., Shannon, N., Heaney, J., Hoare, M., Marshall, A., Alexander, G.J., 2014. The senescent hepatocyte gene signature in chronic liver disease. Exp. Gerontol. $60,37-45$. 
Artursson, P., Palm, K., Luthman, K., 2001. Caco-2 monolayers in experimental and theoretical predictions of drug transport. Adv. Drug Deliv. Rev. 46, 27-43.

Banning, A., Brigelius-Flohe, R., 2005. NF-kappaB, Nrf2, and HO-1 interplay in redoxregulated VCAM-1 expression. Antioxid. Redox Signal. 7, 889-899.

Beltran-Ramirez, O., Sokol, S., Le-Berre, V., Francois, J.M., Villa-Trevino, S., 2010. An approach to the study of gene expression in hepatocarcinogenesis initiation. Transl. Oncol. 3, 142-148.

Benhar, M., Engelberg, D., Levitzki, A., 2002. ROS, stress-activated kinases and stress signaling in cancer. EMBO Rep. 3, 420-425.

Braun, T., Carvalho, G., Fabre, C., Grosjean, J., Fenaux, P., Kroemer, G., 2006. Targeting NF-kappaB in hematologic malignancies. Cell Death Differ. 13, 748-758.

Briede, J.J., van Delft, J.M., de Kok, T.M., van Herwijnen, M.H., Maas, L.M., Gottschalk, R.W., Kleinjans, J.C., 2010. Global gene expression analysis reveals differences in cellular responses to hydroxyl- and superoxide anion radical-induced oxidative stress in caco-2 cells. Toxicol. Sci. 114, 193-203.

Bruix, J., Boix, L., Sala, M., Llovet, J.M., 2004. Focus on hepatocellular carcinoma. Cancer Cell 5, 215-219.

Cavill, R., Kleinjans, J., Briede, J.J., 2013. DTW4Omics: comparing patterns in biological time series. PLoS ONE 8, e71823.

Chan, K., Han, X.D., Kan, Y.W., 2001. An important function of Nrf2 in combating oxidative stress: detoxification of acetaminophen. Proc. Natl. Acad. Sci. USA 98, 4611-4616.

D’Autreaux, B., Toledano, M.B., 2007. ROS as signalling molecules: mechanisms that generate specificity in ROS homeostasis. Nat. Rev. Mol. Cell Biol. 8, 813-824.

Deferme, L., Briede, J.J., Claessen, S.M., Jennen, D.G., Cavill, R., Kleinjans, J.C., 2013. Time series analysis of oxidative stress response patterns in HepG2: a toxicogenomics approach. Toxicology 306, 24-34.

Duthie, S.J., Collins, A.R., 1997. The influence of cell growth, detoxifying enzymes and DNA repair on hydrogen peroxide-mediated DNA damage (measured using the comet assay) in human cells. Free Radic. Biol. Med. 22, 717-724.

Ernst, J., Bar-Joseph, Z., 2006. STEM: a tool for the analysis of short time series gene expression data. BMC Bioinformatics 7, 191.

Forman, H.J., Maiorino, M., Ursini, F., 2010. Signaling functions of reactive oxygen species. Biochemistry 49, 835-842.

Franke, T.F., Kaplan, D.R., Cantley, L.C., 1997. PI3K: downstream AKTion blocks apoptosis. Cell 88, 435-437.

Fredriksson, L., Wink, S., Herpers, B., Benedetti, G., Hadi, M., de Bont, H., Groothuis, G., Luijten, M., Danen, E., de Graauw, M., Meerman, J., van de Water, B., 2014. Drug-induced endoplasmic reticulum and oxidative stress responses independently sensitize toward TNFalpha-mediated hepatotoxicity. Toxicol. Sci. $140,144-159$

Furumatsu, K., Nishiumi, S., Kawano, Y., Ooi, M., Yoshie, T., Shiomi, Y., Kutsumi, H., Ashida, H., Fujii-Kuriyama, Y., Azuma, T., Yoshida, M., 2011. A role of the aryl hydrocarbon receptor in attenuation of colitis. Dig. Dis. Sci. 56, 25322544.

Ganan-Gomez, I., Wei, Y., Yang, H., Boyano-Adanez, M.C., Garcia-Manero, G., 2013. Oncogenic functions of the transcription factor Nrf2. Free Radic. Biol. Med.

Giannoni, E., Parri, M., Chiarugi, P., 2012. EMT and oxidative stress: a bidirectional interplay affecting tumor malignancy. Antioxid. Redox Signal. 16, 1248-1263.

Gmeiner, W.H., Hellmann, G.M., Shen, P., 2008. Tissue-dependent and -independent gene expression changes in metastatic colon cancer. Oncol. Rep. 19, 245-251.

Grivennikov, S.I., 2013. Inflammation and colorectal cancer: colitis-associated neoplasia. Semin. Immunopathol. 35, 229-244.

Hebels, D.G., Briede, J.J., Khampang, R., Kleinjans, J.C., de Kok, T.M., 2010. Radical mechanisms in nitrosamine- and nitrosamide-induced whole-genome gene expression modulations in Caco-2 cells. Toxicol. Sci. 116, 194-205.

Hollensworth, S.B., Shen, C., Sim, J.E., Spitz, D.R., Wilson, G.L., LeDoux, S.P., 2000. Glial cell type-specific responses to menadione-induced oxidative stress. Free Radic. Biol. Med. 28, 1161-1174.

Huo, L., Li, C.W., Huang, T.H., Lam, Y.C., Xia, W., Tu, C., Chang, W.C., Hsu, J.L., Lee, D.F., Nie, L., Yamaguchi, H., Wang, Y., Lang, J., Li, L.Y., Chen, C.H., Mishra, L., Hung, M.C., 2014. Activation of Keap1/Nrf2 signaling pathway by nuclear epidermal growth factor receptor in cancer cells. Am. J. Transl. Res. 6, 649-663.

Ijssennagger, N., Rijnierse, A., de Wit, N.J., Boekschoten, M.V., Dekker, J., Schonewille, A., Muller, M., van der Meer, R., 2013. Dietary heme induces acute oxidative stress, but delayed cytotoxicity and compensatory hyperproliferation in mouse colon. Carcinogenesis 34, 1628-1635.

Itzkowitz, S.H., Yio, X., 2004. Inflammation and cancer IV. Colorectal cancer in inflammatory bowel disease: the role of inflammation. Am. J. Physiol. Gastrointest. Liver Physiol. 287, G7-G17.

Iwanaga, K., Yang, Y., Raso, M.G., Ma, L., Hanna, A.E., Thilaganathan, N., Moghaddam, S., Evans, C.M., Li, H., Cai, W.W., Sato, M., Minna, J.D., Wu, H., Creighton, C.J., Demayo, F.J., Wistuba, I.I., Kurie, J.M., 2008. Pten inactivation accelerates oncogenic K-ras-initiated tumorigenesis in a mouse model of lung cancer. Cancer Res. 68, 1119-1127.

Jarrett, S.G., Albon, J., Boulton, M., 2006. The contribution of DNA repair and antioxidants in determining cell type-specific resistance to oxidative stress. Free Radic. Res. 40, 1155-1165.

Jennen, D.G., Magkoufopoulou, C., Ketelslegers, H.B., van Herwijnen, M.H., Kleinjans, J.C., van Delft, J.H., 2010. Comparison of HepG2 and HepaRG by whole-genome gene expression analysis for the purpose of chemical hazard identification. Toxicol. Sci. 115, 66-79.

Jin, J., Xiong, T., Hou, X., Sun, X., Liao, J., Huang, Z., Huang, M., Zhao, Z., 2014. Role of Nrf2 activation and NF-kappaB inhibition in valproic acid induced hepatotoxicity and in diammonium glycyrrhizinate induced protection in mice. Food Chem. Toxicol. 73, 95-104.
Kay, H.Y., Won Yang, J., Kim, T.H., Lee da, Y., Kang, B., Ryu, J.H., Jeon, R., Kim, S.G., 2010. Ajoene, a stable garlic by-product, has an antioxidant effect through Nrf2mediated glutamate-cysteine ligase induction in HepG2 cells and primary hepatocytes. J. Nutr. 140, 1211-1219.

Kim, J., Lee, J.H., Iyer, V.R., 2008. Global identification of Myc target genes reveals its direct role in mitochondrial biogenesis and its E-box usage in vivo. PLoS ONE 3, e1798.

Klaunig, J.E., Kamendulis, L.M., Hocevar, B.A., 2010. Oxidative stress and oxidative damage in carcinogenesis. Toxicol. Pathol. 38, 96-109.

Kundu, J.K., Surh, Y.J., 2012. Emerging avenues linking inflammation and cancer. Free Radic. Biol. Med. 52, 2013-2037.

Lee, J.M., Calkins, M.J., Chan, K., Kan, Y.W., Johnson, J.A., 2003. Identification of the NF-E2-related factor-2-dependent genes conferring protection against oxidative stress in primary cortical astrocytes using oligonucleotide microarray analysis. J. Biol. Chem. 278, 12029-12038.

Lee, J.M., Li, J., Johnson, D.A., Stein, T.D., Kraft, A.D., Calkins, M.J., Jakel, R.J., Johnson, J.A., 2005. Nrf2, a multi-organ protector? FASEB J. 19, 1061-1066.

Limonciel, A., Monks, K., Stanzel, S., Truisi, G.L., Parmentier, C., Aschauer, L., Wilmes A., Richert, L., Hewitt, P., Mueller, S.O., Lukas, A., Kopp-Schneider, A., Leonard, M.O., Jennings, P., 2015. Transcriptomics hit the target: monitoring of ligandactivated and stress response pathways for chemical testing. Toxicol. In Vitro.

Liu, G.H., Qu, J., Shen, X., 2008. NF-kappaB/p65 antagonizes Nrf2-ARE pathway by depriving CBP from Nrf2 and facilitating recruitment of HDAC3 to MafK. Biochim. Biophys. Acta 1783, 713-727.

Liu, W., Baker, S.S., Baker, R.D., Nowak, N.J., Zhu, L., 2011. Upregulation of hemoglobin expression by oxidative stress in hepatocytes and its implication in nonalcoholic steatohepatitis. PLoS ONE 6, e24363.

Liu, Z., Wu, X., Zhang, F., Han, L., Bao, G., He, X., Xu, Z., 2013. AhR expression is increased in hepatocellular carcinoma. J. Mol. Histol. 44, 455-461.

Livak, K.J., Schmittgen, T.D., 2001. Analysis of relative gene expression data using real-time quantitative PCR and the 2(-Delta Delta $C(T)$ ) method. Methods 25, 402-408.

Llovet, J.M., Burroughs, A., Bruix, J., 2003. Hepatocellular carcinoma. Lancet 362, 1907-1917.

Lu, S.C., 2013. Glutathione synthesis. Biochim. Biophys. Acta 1830, 3143-3153.

Malik, N., Efthymiou, A.G., Mather, K., Chester, N., Wang, X., Nath, A., Rao, M.S. Steiner, J.P., 2014. Compounds with species and cell type specific toxicity identified in a 2000 compound drug screen of neural stem cells and rat mixed cortical neurons. Neurotoxicology 45, 192-200.

MAOC Consortium, Shi, L., Reid, L.H., Jones, W.D., Shippy, R., Warrington, J.A., Baker S.C., Collins, P.J., de Longueville, F., Kawasaki, E.S., Lee, K.Y., Luo, Y., Sun, Y.A. Willey, J.C., Setterquist, R.A., Fischer, G.M., Tong, W., Dragan, Y.P., Dix, D.J., Frueh, F.W., Goodsaid, F.M., Herman, D., Jensen, R.V., Johnson, C.D., Lobenhofer, E.K., Puri, R.K., Schrf, U., Thierry-Mieg, J., Wang, C., Wilson, M., Wolber, P.K., Zhang, L., Amur, S., Bao, W., Barbacioru, C.C., Lucas, A.B., Bertholet, V., Boysen, C. Bromley, B., Brown, D., Brunner, A., Canales, R., Cao, X.M., Cebula, T.A., Chen, J.J., Cheng, J., Chu, T.M., Chudin, E., Corson, J., Corton, J.C., Croner, L.J., Davies, C., Davison, T.S., Delenstarr, G., Deng, X., Dorris, D., Eklund, A.C., Fan, X.H., Fang, H., Fulmer-Smentek, S., Fuscoe, J.C., Gallagher, K., Ge, W., Guo, L., Guo, X., Hager, J., Haje, P.K., Han, J., Han, T., Harbottle, H.C., Harris, S.C., Hatchwell, E., Hauser, C.A., Hester, S., Hong, H., Hurban, P., Jackson, S.A., Ji, H., Knight, C.R., Kuo, W.P., LeClerc, J.E., Levy, S., Li, Q.Z., Liu, C., Liu, Y., Lombardi, M.J., Ma, Y., Magnuson, S.R., Maqsodi, B., McDaniel, T., Mei, N., Myklebost, O., Ning, B., Novoradovskaya, N., Orr, M.S., Osborn, T.W., Papallo, A., Patterson, T.A., Perkins, R.G., Peters, E.H. Peterson, R., Philips, K.L., Pine, P.S., Pusztai, L., Qian, F., Ren, H., Rosen, M. Rosenzweig, B.A., Samaha, R.R., Schena, M., Schroth, G.P., Shchegrova, S., Smith, D.D., Staedtler, F., Su, Z., Sun, H., Szallasi, Z., Tezak, Z., Thierry-Mieg, D., Thompson, K.L., Tikhonova, I., Turpaz, Y., Vallanat, B., Van, C., Walker, S.J., Wang, S.J., Wang, Y., Wolfinger, R., Wong, A., Wu, J., Xiao, C., Xie, Q., Xu, J., Yang, W., Zhang, L., Zhong, S., Zong, Y., Slikker Jr., W., 2006. The MicroArray Quality Control (MAQC) project shows inter- and intraplatform reproducibility of gene expression measurements. Nat. Biotechnol. 24, 1151-1161.

Nakajima, S., Kitamura, M., 2013. Bidirectional regulation of NF-kappaB by reactive oxygen species: a role of unfolded protein response. Free Radic. Biol. Med. 65C, $162-174$.

Patterson, T.A., Lobenhofer, E.K., Fulmer-Smentek, S.B., Collins, P.J., Chu, T.M., Bao, W., Fang, H., Kawasaki, E.S., Hager, J., Tikhonova, I.R., Walker, S.J., Zhang, L., Hurban, P., de Longueville, F., Fuscoe, J.C., Tong, W., Shi, L., Wolfinger, R.D., 2006. Performance comparison of one-color and two-color platforms within the MicroArray Quality Control (MAQC) project. Nat. Biotechnol. 24, 1140-1150.

Pavlick, K.P., Laroux, F.S., Fuseler, J., Wolf, R.E., Gray, L., Hoffman, J., Grisham, M.B. 2002. Role of reactive metabolites of oxygen and nitrogen in inflammatory bowel disease. Free Radic. Biol. Med. 33, 311-322.

Pez, F., Lopez, A., Kim, M., Wands, J.R., Fromentel, C.C., Merle, P., 2013. Wnt signaling and hepatocarcinogenesis: molecular targets for the development of innovative anticancer drugs. J. Hepatol.

Quan, X., Lim, S.O., Jung, G., 2011. Reactive oxygen species downregulate catalase expression via methylation of a CpG island in the Oct-1 promoter. FEBS Lett. 585, 3436-3441.

Ramos-Gomez, M., Kwak, M.K., Dolan, P.M., Itoh, K., Yamamoto, M., Talalay, P., Kensler, T.W., 2001. Sensitivity to carcinogenesis is increased and chemoprotective efficacy of enzyme inducers is lost in nrf2 transcription factor-deficient mice. Proc. Natl. Acad. Sci. USA 98, 3410-3415.

Ramos-Gomez, M., Dolan, P.M., Itoh, K., Yamamoto, M., Kensler, T.W., 2003. Interactive effects of nrf2 genotype and oltipraz on benzo[a]pyrene-DNA adducts and tumor yield in mice. Carcinogenesis 24, 461-467. 
Rangasamy, T., Cho, C.Y., Thimmulappa, R.K., Zhen, L., Srisuma, S.S., Kensler, T.W., Yamamoto, M., Petrache, I., Tuder, R.M., Biswal, S., 2004. Genetic ablation of Nrf2 enhances susceptibility to cigarette smoke-induced emphysema in mice. J. Clin. Invest. 114, 1248-1259.

Rauch, J., Kolch, W., Mahmoudi, M., 2012. Cell type-specific activation of AKT and ERK signaling pathways by small negatively-charged magnetic nanoparticles. Sci. Rep. 2, 868.

Reuter, S., Gupta, S.C., Chaturvedi, M.M., Aggarwal, B.B., 2010. Oxidative stress, inflammation, and cancer: how are they linked? Free Radic. Biol. Med.

Sauer, H., Wartenberg, M., Hescheler, J., 2001. Reactive oxygen species as intracellular messengers during cell growth and differentiation. Cell. Physiol. Biochem. 11, 173-186.

Staal, Y.C., Hebels, D.G., van Herwijnen, M.H., Gottschalk, R.W., van Schooten, F.J., van Delft, J.H., 2007. Binary PAH mixtures cause additive or antagonistic effects on gene expression but synergistic effects on DNA adduct formation. Carcinogenesis 28, 2632-2640.

Sun, X.F., Zhang, H., 2007. NFKB and NFKBI polymorphisms in relation to susceptibility of tumour and other diseases. Histol. Histopathol. 22, 1387-1398.
Sun, Z., Wu, T., Zhao, F., Lau, A., Birch, C.M., Zhang, D.D., 2011. KPNA6 (Importin \{alpha\}7)-mediated nuclear import of Keap1 represses the Nrf2-dependent antioxidant response. Mol. Cell. Biol. 31, 1800-1811.

Tilton, S.C., Karin, N.J., Tolic, A., Xie, Y., Lai, X., Hamilton Jr., R.F., Waters, K.M., Holian, A. Witzmann, F.A., Orr, G., 2014. Three human cell types respond to multiwalled carbon nanotubes and titanium dioxide nanobelts with cell-specific transcriptomic and proteomic expression patterns. Nanotoxicology 8, 533-548. Tudek, B., Winczura, A., Janik, J., Siomek, A., Foksinski, M., Olinski, R., 2010. Involvement of oxidatively damaged DNA and repair in cancer development and aging. Am. J. Transl. Res. 2, 254-284.

Wang, Z., Li, Y., Sarkar, F.H., 2010. Signaling mechanism(s) of reactive oxygen species in Epithelial-Mesenchymal Transition reminiscent of cancer stem cells in tumor progression. Curr. Stem Cell Res. Ther. 5, 74-80.

Xie, J., Shaikh, Z.A., 2006. Cadmium-induced apoptosis in rat kidney epithelial cells involves decrease in nuclear factor-kappa B activity. Toxicol. Sci. 91, 299-308. 